\title{
UNIVERSITYOF
}

FORWARD

THINKING

WESTMINSTER用

WestminsterResearch

http://www.westminster.ac.uk/westminsterresearch

Politics, Legal Concerns, and Reforms

Avery, S.

This is the accepted version of the text, prior to publishers typesetting, of a chapter published in Long Hoeveler, D. and Denenholz Morse, D. (eds.) Blackwell Companion to the Brontes, Oxford, Wiley, pp. 471-484, which has been published in final form, with details at:

http://eu.wiley.com/WileyCDA/WileyTitle/productCd-1118404947.html

(C 2016 John Wiley \& Sons, Ltd. Published 2016 by John Wiley \& Sons, Ltd.

The WestminsterResearch online digital archive at the University of Westminster aims to make the research output of the University available to a wider audience. Copyright and Moral Rights remain with the authors and/or copyright owners.

Whilst further distribution of specific materials from within this archive is forbidden, you may freely distribute the URL of WestminsterResearch: ((http://westminsterresearch.wmin.ac.uk/)).

In case of abuse or copyright appearing without permission e-mail repository@westminster.ac.uk 


\section{Politics, Legal Concerns, and Reforms}

\section{Simon Avery}

In 1857, Elizabeth Gaskell published her major contribution to the developing genre of nineteenth-century biography, her complex and subsequently much-debated Life of Charlotte Brontë. As one of the first biographies of one woman writer by another, produced from what Gaskell termed "this grave duty" (Letters 1997, 349), the Life is a crucial text in Brontë criticism—even if its narrative drive and processes of selecting evidence are complicated by Gaskell's overriding desire to emphasize Brontë’s deep-rooted stoicism, Christian humility, and struggle against the odds. Writing the biography directly after her novels Ruth (1853) and North and South (1855), Gaskell almost models Brontë as one of her own female fictional protagonists as she seemingly endure hardship and oppression at the hands of her family, dominant social structures, and established gender expectations. Indeed, while the Life emphasizes Brontë's extreme will to power in her drive to be published, it also insistently constructs her as a martyr figure — even, as Angus Easson highlights, as a female Christ figure at one point (Life 296; 541).

While this version of the life, along with its attendant mythologizing of the "Brontë country" of the West Riding of Yorkshire, has been challenged by subsequent biographers and critics such as Edward Chitham (1987), Juliet Barker (1994), and Lucasta Miller (2001), Gaskell's work is interesting for the ways in which it opened up—albeit often in passing — the idea of the Brontës' engagement with various social, political, and legal debates of the period. For intertwined with the narrative of Charlotte's development as a successful writer is discussion of industrialized Keighley and its "new modes of thinking" (Life 9), the process of local landowners turning to manufacturing, the Luddite riots, contemporary religious debates, 
Charlotte's perceptions of the politics of continental Europe, and the importance of history to political understanding. By the early decades of the twentieth century, however, recognition of this sociopolitical engagement had started to be elided in both biographical and critical works. Central to this process was a complicated nexus of factors including the entrenchment of the (in-)famous Brontë "cult" (to which, of course, Gaskell's own text contributed); the modernist backlash against Victorian literature generally; and the development of English Studies as a discipline with its attendant debates around canon formation and the somewhat nebulous category of "women's writing."

This elision continued to be fostered in much criticism of the postwar period to the extent that, in the opening to his ground-breaking Myths of Power: A Marxist Study of the Brontës, published in 1975, Terry Eagleton could speak of an established trend that viewed the writers as "the three weird sisters deposited on the Yorkshire moors from some metaphysical outer space" (Eagleton 2005, 3). This is an astonishing phrasing, which seemingly constructs the Brontës as an amalgam of the classical Fates and the witches from Macbeth, disconnected from all social structures. Indeed, it is intriguing that this overly romanticized view of the Brontës would be lent even greater currency three years later when Kate Bush's debut single, "Wuthering Heights" (released January 1978), forcefully made its way to the top of the music charts in the United Kingdom as well as Ireland, Italy, Australia, and New Zealand. Initially inspired by the last part of the 1970 film adaptation starring Anna Calder-Marshall and Timothy Dalton (Thomson 2012, 91), Bush's densely layered song and the accompanying video-with its persona of the ghostly Catherine Earnshaw as a cross between ostracized waif and femme fatale, its operatic-style vocals, and its strangely stylized choreography_effectively foregrounded precisely that kind of otherworldly, ahistorical construction of the Brontës and their works against which Eagleton's study staked its claim. Certainly, the notion of the Brontës as untutored geniuses, isolated in the parsonage at the top 
of the steep Haworth main street and escaping to the moors from which those astonishing texts Jane Eyre, Wuthering Heights, and The Tenant of Wildfell Hall seemed to emerge unbidden, has been particularly hard to dislodge.

Such a notion often tells us more about our own attraction to (and possible need for) a particular fabrication of the Brontës at specific historical moments than it does about their actual engagement with the rapidly changing world around them in the first half of the nineteenth century. For as Lucasta Miller notes (2001, xi), the "Brontë myth"—itself fascinating in so many ways - has a "penumbra of emotional, aesthetic and ideological resonances [...] clustered around it." In the last few decades, however, new critical emphases, particularly emerging from strands of feminist, materialist, and historicist thinking, have complicated our understanding of the relations between the Brontës and their immediate, national, and international environs. One important strand of this work has been a wider and more subtle understanding of the importance of politics and political thinking for the family. Reflections on Tory and Whig government policy, the push for reform, concepts of nationalism and revolution, notions of leadership, colonialism, the impact of industrialization and class antagonism, abolitionist movements, the emerging "Woman Question," mechanisms of political change, and war and militarized violence-all these issues thread through the siblings' letters, poems, stories, essays, and novels from the 1820 s to the 1850 s. Moreover, as critics such as Maria Aristodemou (2000) and Ian Ward (2012) have begun to reveal, the Brontë novels are full of significant references to legal concerns, including aspects of marriage, property and custody law, spousal and child abuse, and the practices of confinement. For as Eagleton rightly asserts, "[t]he Brontës lived through an era of disruptive social change, and lived that disruption at a peculiarly vulnerable point" $(2005,7)$. 
In this chapter, I examine the ways in which the Brontës' writings engage with, and reflect upon, a range of these political and legal concerns. I am particularly interested here in the means by which the Brontës' thinking about politics was formed and shaped in their work prior to the production of their mature fiction. Starting with the early influences on the family, I trace their political awareness through the construction of the imaginary lands of Angria and Gondal and subsequently into their poetry, both that which remained private and that which was published either in newspapers and periodicals (in Branwell's case) or in the ill-fated Poems by Currer, Ellis and Acton Bell (1846). In this reading, the often-overlooked writings of Patrick and Branwell are seen to be more significant than they are often acknowledged to be. Certainly, as I argue more generally, the Brontës' careers offer a fascinating case study of the ways in which literature can reflect upon politics, legislation, and reform—and itself be seen to have political work to do—in one of the most fundamentally undemocratic periods of modern history. Such "heretic narratives" of political engagement— to borrow a phrasing from Lucy Snowe (Villette 228)—are both fascinating and revealing for our understanding of the Brontës' contributions to nineteenth-century literary and intellectual culture.

\section{Early Influences and Political Development}

The Brontë siblings' concern with politics sprang in part from their family's Irish background and particularly the political stance of their father, Patrick. Born in 1777, Patrick was brought up in a Protestant family in County Down and throughout his life, and that of his children, Ireland would remain England's oldest colony. Patrick's relationship to English politics and culture was therefore highly complex despite—or maybe because of—his residence in England for most of his life. In 1798, his brother William, a member of the Society of United 
Irishmen who were inspired by the ideals of the French Revolution, fought at the famous Battle of Ballynahinch where the Irishmen were defeated by government forces. This was a defeat that led, Juliet Barker argues (1994, 3-4), to both an anxiety on Patrick's part about rebellion and revolt in general and his strong support for maintaining the 1801 Act of Union in particular. Patrick frequently spoke of Irish politics in his correspondence and, as Edward Chitham has documented in his book-length study on the topic, Patrick's Irish background would infuse his subsequent work and thought, and that of his children, in multiple ways. As a type of the self-made man which was widely promoted in nineteenth-century intellectual and political cultures, Patrick established a school when aged just sixteen and worked his way through Cambridge University in a way which demonstrates his belief in the transformative potential of education for both the politically marginalized individual and the politics of the nation state more generally - ideas to which his daughters would repeatedly draw attention in their mature fiction. (As Marianne Thormählen has emphasized [2007, 4], Charlotte and Anne in particular reiterate "the duty [of their protagonists] to improve themselves through (self-)education.") Interestingly, too, it seems to have been at Cambridge that Patrick changed his name from Brunty to Brontë, possibly because of its associations with Horatio Nelson who was made Duke of Brontë by King Ferdinand I of Sicily in 1799 for helping defeat Napoleon's invading forces. If this was Patrick's reasoning, it was a bold move that might be read as helping to establish that fascination with military leaders which would later inspire the family generally (in 1841 Branwell would write a celebratory poem on Nelson entitled "The Triumph of Mind Over Body" where he addresses him as the "kingdoms [sic] noblest son” (1. 26), for example, and Charlotte's Shirley Keelder refers to him as being "great at heart as a Titan [and] gallant and heroic as all the world and age of chivalry" [Shirley 524]). Certainly, the figure of the male hero and the attendant practice of hero worship—ideas which were pervasive in nineteenth-century thought, particularly through Thomas Carlyle's 
On Heroes, Hero-Worship and the Heroic in History (1841)—were to become fundamental to the development of the Brontës' political writings.

As a writer himself, Patrick evidently recognized the political potential of literature. In his own poetry publications-Winter Evening Thoughts (1810), Cottage Poems (1811), and The Rural Minstrel (1813), which appeared at the same time as the work of poets like Wordsworth, Byron, and Felicia Hemans-he relies on what he terms his "rustic muse" ("Epistle to the Rev. J- B-," ll. 1) in order to emphasize the suffering of the poor and to express, in a simple and direct way, the importance of religion to a fulfilling life. Patrick's general aim here therefore reflected that belief in the democratic access to ideas through the language "really used by men" [sic] which Wordsworth argued for in his 1802 Preface to Lyrical Ballads (2000, 597). Arguably more significant with regard to politics, however, is Patrick's anonymously published fiction, The Maid of Killarney: A Modern Tale. Appearing in 1818 , this text was the product of a particularly tense political moment as Britain struggled economically, socially, and politically in the period following the cessation of the war with France in 1815. Widespread economic depression, strikes and machine breaking, higher taxation, rising food prices, and renewed campaigning for suffrage and parliamentary reform meant that the immediate postwar years - the years in which the Brontë children were bornwitnessed frequent demonstrations across the country. Lord Liverpool's Tory government responded with increasingly draconian legislation, including the suspension of Habeas Corpus in 1817—which meant that any suspected agitator could be imprisoned without first having to appear in court—and, following the 1819 Peterloo Massacre, the implementation of the infamous Six Acts which prohibited public gatherings, restricted freedom of the press, and banned publications likely to incite hatred of the government. Within this context, Patrick's Maid of Killarney takes on particularly significant political resonances. Set in Brontë's contemporary Ireland, the tale centers on an English hero, the unsubtly named 
Albion, who falls in love with an Irish woman called Flora and eventually marries her in what might be read as a kind of symbolic Anglo-Irish union. Interspersed with this narrative, as the novel's subtitle indicates, are "some cursory remarks on religion and politics," including reflections on Catholic emancipation, poverty, and the relations between the gentry and the workers, as well as the need to reform capital punishment. Although Patrick's writings are undoubtedly aesthetically limited—his biographer, Dudley Green, sees them as "uneven and clearly not of great literary merit" (2008, 180), while Eagleton (1995, 18n.48) dismisses Maid of Killarney as an "abysmal Irish novella" - they nevertheless embody to some degree that conscious questioning of dominant sociopolitical structures and hierarchies that his daughters would make a key strategy in their far more powerful works.

As Gaskell notes in the Life, one of the key intellectual concerns that Patrick Brontë shared with his children, and which they eagerly took up, was his "vivid interest in the public characters, and the local and the foreign as well as home politics discussed in the newspapers” (48). Indeed, “[p]olitics was evidently their great interest,” Gaskell later reemphasizes (72). Patrick's political stance was essentially Tory, although this was heavily tempered by a commitment to liberal reform and tolerance. In 1829, for example, Patrick wrote two letters to the Leeds Intelligencer in support of the Catholic Emancipation Act. Catalyzed by the case of Daniel O'Connell, who won election to Parliament but could not sit because of his religion, this Act overturned the seventeenth-century Corporation and Test Acts barring Catholics from being MPs or holding other public offices. Although Patrick was critical of Catholicism per se and particularly its ritual and perceived "popery" — as Charlotte so obviously would be, too, as seen in her letters from Belgium as well as The Professor and Villette-he was nevertheless committed to the civil rights of the individual. In the early 1830s, Patrick would extend this commitment in his support for that key piece of Whig legislation, the First Reform Bill (passed 1832)—much to the indignation of many of his 
Tory friends, as Juliet Barker notes $(1994,178)$. In its concern with restructuring the franchise by reducing rotten boroughs and bringing about direct representation for the new manufacturing and commercial interests, the passing of the Bill would usher in a decade of modernizing reform. Moreover, Patrick was a great believer in the power of the petition, organizing a petition against slavery in 1830 which was sent to both Houses of Parliament (slavery in British colonies would finally be abolished in 1833), and, in 1837, organizing a meeting and a petition calling for the repeal of the 1834 Poor Law Amendment Act which had brought in the brutal system of workhouses in England and Wales (for more on these issues, see Dudley Green's discussion in Chapter 12 of this volume). As Patrick noted in a letter to his friend Elizabeth Franks, he remained committed to the state and the establishment but nevertheless advocated "moderate, or temperate reform," arguing that he saw this as "an affair of conscience and judgment" (qtd. Green 2008, 189). Patrick's surviving children generally followed their father's political allegiance, although at times Charlotte interestingly appears more staunchly Tory than her father ever was, particularly in her opposition to the First Reform Bill and her bitter disappointment when it was finally passed through the Lords. Significantly, the family read widely in newspapers and journals of different political persuasions - the Whig Leeds Mercury found its way into the parsonage as well as the Tory Leeds Intelligencer and Blackwood's Magazine and the "High Tory" John Bull (Barker in Glen 2002, 24) — and consequently they were used to debating issues from a variety of perspectives. Given this political alertness, then, it is not surprising that the Brontë children's first literary formations were founded upon a particular kind of Romantic politics. For with that famous gift from Patrick to Branwell of a box of twelve toy soldiers in June 1826, the Brontë children created a series of literary worlds firmly rooted in revolution, violence, and the struggle for political power. 
As Christine Alexander has noted in her extensive work on the siblings' early writings, "[t]he stories jointly composed and acted by the Brontës were allegories of political events, a mixture of the real and the purely fictional" (in Thormählen 2012, 99). In many ways the establishment of Glass Town, and the subsequent configurations of Angria and Gondal, were a means by which the children could engage with any number of contemporary and near-contemporary political debates and issues. The fact that Branwell and Charlotte respectively named their chief soldiers after Napoleon Bonaparte and the Duke of Wellington (who had become prime minister the previous year) clearly indicates both their initial investment in narratives of the recent Napoleonic Wars and the focus of political antagonism as a galvanizing principle for their juvenilia. Indeed, Victor Neufeldt has pointed to the children's fascination with the accounts of both the Napoleonic and American Revolutionary Wars in Blackwood's Magazine (in Thormählen 2012, 53.) Emily and Anne's decision to name their soldiers after the early-nineteenth-century Arctic explorers William Edward Parry and John Ross can also be seen to lock into contemporary events and (politicized) concerns with territorial investigation and expansion. Certainly Glass Town, set in a fictionalized West Africa where the indigenous Ashantee peoples are subject to frequent massacres from the invading Twelves (the soldiers), enabled the children to fabricate a world which-implicitly at least—both enacts processes of colonization and reflects upon those ideologies of nationalism and nation building which were central to the geopolitics of early-to-midnineteenth-century Europe. For Glass Town constituted a world of political intrigue and social unrest, battles for leadership and the concern with the policing of borders-a world which the children documented in stories, dramas, histories, and poems in those miniature manuscripts which were meant, on one level at least, to replicate contemporary print culture. Charlotte would remain committed to composing narratives of Glass Town and Angria until 1839, producing that substantial body of work which Gaskell believed was evidence, as she 
wrote to George Smith, of "creative power carried to the verge of insanity" (Letters 398). While Charlotte's narratives may reveal, as Heather Glen argues (2006, xii), a critique of Branwell's obsessive militarism and an increasing concern with romantic relationships and the satirizing of aristocratic life (particularly in the late "Mina Laury" and "Henry Hastings"), they are nevertheless clearly situated in a framework of recognizable political contexts and scenarios, relating to patterns of social mobility, the role of the new manufacturing interests, and practices of international diplomacy and colonialism. Indeed, in a particularly insightful postcolonial reading, Carl Plasa has uncovered how Charlotte's early stories reveal a key concern with, and anxiety about, exoticism and miscegenation, as well as a fear of "interracial desire and rebellious hybridity" $(2004,6)$. As Plasa notes, these works are consequently "fully implicated [...] in the colonial enterprise with which they are coeval" (3). Like much fantasy writing, therefore, Charlotte's narratives effectively reflect upon their own moment of production.

Branwell's poetry from this period—work which is arguably the least critically examined in the Brontë canon-clearly demonstrates his committed investment in the political concerns of the Glass Town/Angria saga. The poems repeatedly foreground that opposing rhetoric of liberty and oppression which would become central to all the Brontës' mature works, and which for Branwell is often linked to ideas of nationalism and national self-determination. "O when shall our brave land be free," opens a poem of July 24, 1829, for example; "when shall our castles rise / in pure \& glorious liberty / before our joyful eyes" (1l. 1-4). In another poem of the same month, Branwell uses the figure of Alexander Soult, the Glass Town poet who was modeled on one of Napoleon's key generals, Marshal Jean-deDieu Soult (Barker 1994, 159), to issue a warning to France, with whom the Glass Town inhabitants are also at war: "Kingdom of France I bid thee beware / at the storm which is drawing nigh / Look at the troubled \& darkening air / Look at the wrath in mine eye" (11. 13- 
16). As Carol Bock has noted, Angrian figures often combine a commitment to politics and a commitment to the arts (in Glen 2002, 40.) And in a short poem composed the previous month, the speaker celebrates the passing of an unspecified government bill in a manner which seems to anticipate the passing of the First Reform Bill: "the bill it [h]as past / at last at last-/ it has past like the sun in his glory" (11. 1-3). Indeed, the idea of nation building was so inherent in the children's construction of the Glass Town Confederacy that Branwell even developed a constitution and legal system for it.

Glass Town and Angria also opened up wider political perspectives for Branwell's poetry, as evidenced, for example, in his "Ode to Napoleon" (September 1829). In this work, the speaker commences by addressing Napoleon as "great [...] son of storms" (1. 1) and seemingly celebrating his career from Austerlitz onward, before playfully turning to acknowledge that this has all been a satirical stance which "of thee [Napoleon] makes fun" and "diminish[es] / Thy most splendid height and grate [sic] glory" (1l. 50; 55). Although relatively undistinguished as a literary production, the poem is nevertheless intriguing for the way in which the shift in argument enables Branwell to dismantle the rhetoric of heroism and triumphant militarism. A decade later, he would return to this poetic engagement with conflict in the more confident and assured poem, "The Afghan War," a work published in the Leeds Intelligencer on May 7, 1842 as one of nearly twenty poems that Branwell was able to place in the press (Neufeldt in Thormählen 2012, 57). This poem opens conventionally with that common Brontëan trope of a figure in the domestic space listening to the (simultaneously literal and metaphorical) "howling weather" outside (1. 19). It is not long, however, before the speaker's thoughts turn to the ongoing Anglo-Afghan War (1839-1842), which was being fought between the British East India Company and Afghanistan as one of the key conflicts in what became known as "The Great Game" (the term which the British diplomat Arthur Conolly coined to refer to the struggle between the British and Russian empires for the 
control of Central Asia). More specifically, the poem was written in direct response to the January 1842 Kabul retreat in which over 16,000 British troops and Indian camp-followers were killed as a result of attacks from Afghan tribesmen, starvation, and hostile weather. Reflecting upon the "uncounted slaughters" which threaten "England's children-England's glory" (11. 39; 43), the speaker calls forcefully on the country to reassert its position of power:

England rise! thine ancient thunder Humbled mightier foes than these;

Broke a whole world's bonds asunder; Gave thee empire o'er the seas.[...]

While one oak thy homes shall shadow, Stand like it as thou hast stood;

While a spring greets grove and meadow, Let not winter freeze thy blood.

'Till this hour St George's standard

Led the advancing march of time.

England! keep it streaming vanward;

Conqueror over age and clime. (11. 49-52; 57-64)

Recalling the earlier Romantic-nationalist poetry of Felicia Hemans, this poem is suffused with an overriding sense of patriotism, emphasized here by the gesturing to past heroic glories, the recourse to a stylized notion of (seemingly specifically English) pastoral, and the establishment of a particular kind of national mythology and cultural politics embodied in the figure of St George. While Branwell clearly had an eye on his potential early-Victorian audience here, the poem signals his position as inheritor of the politically driven agenda of 
many of the Romantic poets—whose works the Brontës avidly read—as well as his ongoing commitment to that political interrogation which Glass Town/Angria had at its core.

Emily and Anne's withdrawal from the Glass Town saga five years into its development and their establishment of the alternative realm of Gondal marked a very different line of political thinking which would be crucial for their mature work, especially in terms of its interrogation of gender relations and patterns of socialization. For rather than the sustained focus on the patriarchal figures of Glass Town, Gondal, structured as a large island in the Pacific, prioritized models of female power, particularly in the figure of the ruler, Augusta Almeda. Emily and Anne's fantasy work consequently situated the possibilities for female leadership and female voices directly into the political sphere, more obviously than even Charlotte's Angrian prose had done. Stevie Davies has noted how the sisters were attracted to the process of "re-enact[ing] the Civil Wars of England and France in the Royalist-republican conflicts of the Gondal Saga" $(1983,29)$. Moreover, it is intriguing how far the politics of Gondal and the politics of the Brontës' own early-nineteenth century overlapped. In her diary paper of June 1837, for example, Emily noted that "the Emperors and Empresses of Gondal and Gaaldine [are] preparing to depart [...] to prepare for the coranation [sic] which will be on $12^{\text {th }}$ July[.] Queen Victoria ascended the throne this month" (qtd. Barker 1994, 271). And in her oft-quoted diary paper from 1834, Emily revealed even more remarkably how the different spheres of her life intersected:

I fed Rainbow, Diamond, Snowflake Jasper phesant [sic] this morning Branwell went down to Mr Drivers and brought news that Sir Robert Peel was going to be invited to stand for Leeds Anne and I have been peeling Apples for Charlotte to make an apple pudding [.... The Gondals are discovering the interior of Gaaldine Sally Mosley is washing in the back Kitchin [sic]. (punctuation as original; qtd. Barker 1994, 220-221). 
What is particularly significant here for our understanding of the Brontës' political engagement is the easy shifting between concerns about the domestic space and concerns about the coming election, the activity of the servants (Sally) and the activities of the Gondal explorers. For as Davies points out, "Gondal is not a sealed world" (1983, 33). In many ways, this diary paper constitutes an early example of that constant intermingling of the "real" and the "imaginary" which would become a central practice of Emily's writing in Wuthering Heights; certainly, it is an intermingling which would remain important to her long after Charlotte had given up Angria and Anne had distanced herself from Gondal. Indeed, as late as 1845 , according to that year's diary paper, Emily was "writing a work on the First [Gondal] Wars" (Barker 1994, 453-454). The prose framework for Gondal may not have survived in the same way as the large number of Angria manuscripts have (a situation which has sometimes led to problematic "reconstructions" such as Fanny Ratchford's 1955 Gondal's Queen: A Novel in Verse), but much of the poetry that Gondal galvanized has. It was this body of work that subsequently contributed to the political dynamics of the sisters' first public foray into the early-Victorian literary marketplace, Poems by Currer, Ellis and Acton Bell.

\section{The Poetry of Political Possibility}

When Charlotte "accidentally lighted" on a manuscript of Emily's poems in late 1845, she rightly recognized that "these were not common effusions, nor at all like poetry women generally write" ("Biographical Notice of Ellis and Acton Bell"). Certainly, in contrast to the writings of established women poets of the period such as Felicia Hemans, Letitia Landon, or Elizabeth Barrett, Emily's poetry appears strangely detached, concentrated, and elliptical. The "peculiar music" that Charlotte identified in Emily's verse had been honed through the 
writing of both the Gondal saga and more obviously personal works (contained principally within the extant Gondal Notebook and Honresfeld manuscript, respectively), and at its best the work evidences a power and intensity comparable with that achieved by any nineteenthcentury poet. The inciting framework of the Gondal narrative is still evident in many of the poems, and these consequently parade their political resonances most obviously. In the opening lines of "Song by Julius Angora" (composed 1837), for example, an intriguing connection between nation states, wild nature, and the conventions of the traditional aubade poem is established, reminiscent of some of Branwell's poems: “Awake! awake! how loud the stormy morning / Calls up to life the nations resting round," the speaker commands, before asserting with patriotic zeal that "no stain is on your country's glory" (1l. 1-2;13). In contrast, the speaker of "Song" ("King Julius left the south country," composed 1839) firmly undercuts the rhetoric of heroic battle by emphasizing, through a strange inversion of time, the seeming inevitability of death: "The sword so bright from battles soon / With unseen rust is fretting / The evening comes before the noon / The scearce [sic] risen sun is setting" (11. 912). Indeed, at "the zenith of his fame" Julius is killed, "[b]oth power and life departed" (ll. 19-20).

It is the non-Gondal or "de-Gondalized" poems, however, which might have more to tell us about Emily's strategic engagement with political systems and ideas in the late 1830s and early 1840s. As Angela Leighton has argued, Emily's stripping away any Gondal references from the works she published in Poems by Currer, Ellis and Acton Bell (1846) reveals "a decision to give the poem[s] free standing-room; to let the play of literal and metaphorical meanings remain unfinished" by their not being defined by any one particular context (in Glen 2002, 55-56). These are, Leighton suggests, “monumentally sparing” poems which often "empty themselves of all merely extraneous distractions of plot or context" (64). Certainly, many of Emily's poems have this overriding sense of "emptiness" and, because of 
their concern with the seeming transcendental, they have often been read as being contextless, a-historical, or a-political. Yet as I have suggested elsewhere (Avery in Thormählen 2012, 263), Emily's poems might also benefit from being read via some of the interpretative strategies that have been applied to the work of poets like Wordsworth and Tennyson. For as critics such as Jerome McGann (1983), Nicolas Roe (1992), and Alan Sinfield (1986) have shown, the ways in which these poets write about nonsocial or marginal environmentsnature in Wordsworth's poetry or the peripheral lands in Tennyson's poetry (in works such as “The Lotus Eaters" and "Ulysses")—simultaneously enables an implicit critique of the perceived problems and systems of oppression at the center of society, "under the sway of dominant ideology" (Sinfield 1986, 39). In these readings of "textual silences" (Roe 1992, 7)—that is, the reflection upon what is noticeably absent from the poem—Wordsworth's principal concern with writing about nature becomes in part a reaction to his despair at the impact of industrialization and the failure of political ideals; and Tennyson's writing about remote lands becomes a way of displacing his anxiety at the fear of possible working-class revolution. If we recall the position of Haworth at the time of the Brontës - at the heart of the West Riding's woolen industry with its attendant social-economic problems (exploitation of the working class in the mills, overcrowding, poor sanitation, and Chartist uprising: see Barker in Glen 2002, 15-18) — then this approach might offer us another way of interpreting the "fond idolatry" of the natural world in Emily's poetry ("Shall Earth no more inspire thee," 1. 16). Repeatedly, Emily's poems (and, later, Wuthering Heights) construct nature as a means of escaping the pressures of sociopolitical structures and expectations, whether this is expressed in the power of a poem like "High Waving Heather" (composed 1836) with its celebration of liberty through the action of the storm and its attendant collapsing of binary oppositions (dark/light, solid/fluid, body/spirit, earth/Heaven); or in the quieter "A little while, a little while" (composed 1838), where the speaker finds solace in the most mundane 
of natural details: "The mute bird sitting on the stone, / The dank moss dripping from the wall, / The garden-walk with weeds o'er-grown / I love them-how I love them all!" (11.1720).

This reading of nature points to the fundamental dialectic of entrapment and escape which, in multiple ways, structures much of Emily's verse. For in seeking to maintain individual identity and integrity in the face of social and political pressures, the speakers and protagonists of Emily's poems look not only to nature as a strategy of resistance but also, in an archetypally Romantic manner, to imaginative and mystical experience. In a poem like "Stars" (composed 1845; published in Poems, 1846), for example, the night sky offers the speaker the ability to transcend the quotidian ("Thought followed thought-through boundless regions on," 11. 13-14) and achieve a unity with the universe which is only broken by the return of the threatening (and, in the gender politics of the poem, masculinized) "[b]lood-red" sun (1. 21). And in "To Imagination" $(1844 ; 1846)$, the "world within" of the mind is addressed as the only place "[w]here thou and I and Liberty / Have undisputed sovereignty" (11. 11-12)—even if, as the speaker admits, imagination's "phantom bliss" (1.31) is not always to be trusted or relied upon. Alternatively, a number of Emily's poems seek a more permanent sense of release than the transient momentariness of mystical/imaginative experience by embracing death as the means of returning to a more "feminized" Mother Earth. In "The linnet in the rocky dells" (1844; published 1846 as "Song"), for example, the emphasis on a benevolent, sustaining nature is tellingly bound up with the celebration of the lady's having escaped the temporal world to become "changed and careless" in the grave: "Blow, west wind, by the lonely mound / And murmur, summer streams; / There is no need of other sound / To soothe my Lady's dreams," the poem concludes (11. 20; 25-28). Here, as elsewhere, death effectively marks the dissolution of social order in the style of Bakhtinian carnival_ _"the feast of becoming, change, and renewal," as Bakhtin puts it (1984, 10)—and 
the poem significantly refuses to gesture toward any notion of an afterlife in an orthodox (patriarchal) heaven. In these readings, then, Emily's poetry becomes highly politicized in its multiple resistances to dominant sociopolitical structures and modes of oppression. For as she expressed it more overtly in "Riches I hold in light esteem" (1841)—the work which was given prominence in the ordering of Poems as Emily's final contribution—capitalist structures and familial and emotional bonds are all essentially meaningless in comparison to the fundamental desire for "a chainless soul" and the "courage to endure" (11. 11-12).

The strategies of resistance inflecting Emily's poetry can also be felt in Anne's tightly controlled verse — a body of work which Isobel Armstrong rightly acknowledges as being "of great subtlety and far wider range than is often thought" $(1993,333)$-and Charlotte's less obviously successful, but still culturally significant, poetic writings. The frequent recourse to depictions of nature in Anne's poetry, whether the powerful, transformative nature of "Lines Composed in a Wood on a Windy Day" (composed 1842; published 1846) or the more tranquil scene in "The Arbour" (composition date unknown; published 1846), functions in much the same way as Emily's nature poetry in both its celebration of liberty and its implicit reflection upon those social and political concerns which the speakers are trying to ameliorate. The frequent emphasis on disenfranchised or isolated figures—such as the oppressed educator in Charlotte's “The Teacher's Monologue” $(1837 ; 1846)$ and the psychologically strained wife of Pontius Pilate in "Pilate's Wife's Dream" (composition date unknown; published 1846), or the struggling believers in Anne's “The Doubter's Prayer" $(1843 ; 1846)$ and "A Word to the 'Elect"” $(1843 ; 1846)$ —reflects in complex ways upon practices of political marginalization and exclusion. And the repeated deployment of images of imprisonment, slavery, and silencing_-particularly where figures lose or are denied their voice: what Charlotte refers to in a poem of 1837 as "[t]he fettered tongue" ("Is this my tomb," 1. 74) — is highly significant at a time when the vast majority of individuals in 
Britain's political structures are disenfranchised. For as Janet Gezari argues $(2007,14)$, the Brontës' poetry can often be read as reflecting upon both gender-specific concerns and those of a wider humanity. Certainly, the dominant image of Anne's poem "The Captive Dove" $(1843 ; 1846)$, where the speaker empathetically laments the creature's lack of liberty_- In vain! In vain! Thou canst not rise-/ Thy prison roof confines thee there" (11. 9-10)—is widely resonant in its sociopolitical interpretive possibilities. This is unsurprising when we recall that the majority of the work contained within Poems by Currer, Ellis and Acton Bell was being composed, edited and published in the midst of the politically volatile "Hungry Forties," the decade that witnessed not only the worst distresses of industrialization to date but also the horrific impact of the Irish Famine. Read in these contexts, then, much of the Brontës' poetry might be seen to interrogate the dominant sociopolitical system which, in Emily’s pseudo-vampiric imagery, "drains the blood of suffering men” (“Stars” 1. 45).

By the time the sisters come to write those fictions for which they are now rightly most famous, they had spent over a decade debating, interrogating and writing about political and legal concerns. Their relationship with Patrick was, on one level at least, founded upon political discussion, and their collaborative projects with Branwell were also fundamentally rooted in political considerations. It is not surprising, then, that this interest never really leaves their subsequent work. For if the Brontës' poetry can be read as exposing a set of sociopolitical concerns and issues—-however obliquely and with an agenda like Emily Dickinson's to "tell [...] the truth" but "tell it slant" $(1975,506)$-then it is in their far more expansive and dialogic fictions that the sisters were able to look for possible solutions to these concerns. Indeed, in their constant examination of aspects of the early-to-mid-Victorian "Woman Question," the institution and legal expectations of marriage, the politics of class relations and industrialization, the possibilities of reform (as articulated most obviously in Anne's Preface to the second edition of The Tenant of Wildfell Hall), and, in Charlotte's case 
at least, the dynamics of international political relations (in The Professor and Villette), the Brontës' novels offer a seemingly inevitable expansion and complication of those issues which had, from the outset, been fundamental to both their lives and their creative endeavor.

\section{References}

Aristodemou, M. (2000). Law and Literature: Journeys from Her to Eternity. Oxford: Oxford University Press.

Armstrong, I. (1993). Victorian Poetry: Poetry, Poetics and Politics. New York: Routledge. Bakhtin, M. (1984). Rabelais and His World. Trans. Hélène Iswolsky. Bloomington: Indiana University Press.

Barker, J. (1994). The Brontës. London: Weidenfeld and Nicolson.

Brontë, A. (1979). The Poems of Anne Brontë: A New Text and Commentary, ed. E. Chitham. London: Macmillan.

Brontë, C. (1985). The Poems of Charlotte Brontë, ed. V. A. Neufeldt. New York and London: Garland Publishing.

Brontë, C. (1979). Shirley, ed. H. Rosengarten and M. Smith. Oxford: Clarendon Press. Brontë, C. (1984). Villette, ed. H. Rosengarten and M. Smith. Oxford: Clarendon Press. Brontë, E.. (1996). The Poems of Emily Brontë, ed. D. Roper and E. Chitham. Oxford: Clarendon Press.

Brontë, P. (1811). Cottage Poems. Halifax: P.K. Holden.

Brontë, P. (1990). The Poems of Patrick Branwell, ed. V. A. Neufeldt. New York and London: Garland Publishing.

Chitham, E. (1986). The Brontës' Irish Background. New York: St Martin's Press. Chitham, E. (1987). A Life of Emily Brontë. Oxford: Basil Blackwell.

Davies, S. (1983). Emily Brontë: The Artist as Free Woman. Manchester: Carcanet Press. Dickinson, E. (1975). The Complete Poems, ed. T. H. Johnson. London: Faber. Eagleton, T. (1995). Heathcliff and the Great Hunger: Studies in Irish Culture. London: Verso.

Eagleton, T. (2005). Myths of Power: A Marxist Study of the Brontës. 3rd edn. Basingstoke: Palgrave Macmillan. 
Gaskell, E. (1997). The Letters of Mrs Gaskell, ed. J. A. V. Chapple and A. Pollard.

Manchester: Mandolin.

Gaskell, E. (2001). The Life of Charlotte Brontë, ed. A. Easson. Oxford World's Classics.

Gezari, J. (2007). Last Things: Emily Brontë's Poems. Oxford: Oxford University Press.

Glen, H. (ed.). (2002). The Cambridge Companion to the Brontës. Cambridge: Cambridge University Press.

Glen, H. (ed.). (2006). Charlotte Brontë: Tales of Angria. London: Penguin.

Green, D. (2008). Patrick Brontë: Father of Genius. Stroud: Nonsuch.

McGann, J. (1983). The Romantic Ideology. Chicago: University of Chicago Press.

Miller, L. (2001). The Brontë Myth. London: Jonathan Cape.

Plasa, C. (2004). Charlotte Brontë. Basingstoke: Palgrave Macmillan.

Ratchford, F. E. (1955). Gondal's Queen: A Novel in Verse. Austin: University of Texas Press.

Roe, N. (1992). The Politics of Nature: William Wordsworth and Some Contemporaries.

Basingstoke and London: Macmillan.

Sinfield, A. (1986). Alfred Tennyson. Oxford: Basil Blackwell.

Thomson, G. (2012). Under the Ivy: The Life and Music of Kate Bush. London: Omnibus Press.

Thormählen, M. (2007). The Brontës and Education. Cambridge: Cambridge University Press.

Thormählen, M. (ed.). (2012). The Brontës in Context. Cambridge: Cambridge University Press.

Ward, I. (2012). Law and the Brontës. Basingstoke: Palgrave Macmillan.

Wordsworth, W. (2000). The Major Works, ed. S. Gill. Oxford: Oxford World's Classics.

\section{Further Reading}

Alexander, C. and M. Smith. (2003). The Oxford Companion to the Brontës. Oxford: Oxford University Press.

A key resource in Brontë studies which offers a wealth of information on aspects of the family's social and political background. 
Briggs, A. (1959; new edition 2000). The Age of Improvement, 1783-1867. Harlow: Longman.

A classic study of the social and political upheavals central to the period in which the Brontës were living and writing.

Davies, S. (1994). Emily Brontë: Heretic. London: Women's Press.

One of the most fascinating analyses of Emily's challenge to social and literary conventions. Davies' reading of "Why ask to know the date—-the clime" is particularly interesting in relation to the politics of Emily's poetry.

Glen, H. (2002). Charlotte Brontë: The Imagination in History. Oxford: Oxford University Press.

A major study which offers fascinating readings of Charlotte's novels revealing her alertness to key debates of the period and her powerful interventions into intellectual history. The discussion of the novels' relations to ideas of history is particularly illuminating. Ingham, P. (2006). The Brontës: Authors in Context. Oxford: Oxford World's Classics. An accessible study covering many aspects of the Brontës' lives and works, particularly useful for tracing their engagement with key social issues of their time.

Lanoff, S. (ed. and trans.). (1997). Charlotte and Emily Brontë: The Belgian Essays: A Critical Edition. New Haven: Yale University Press. An important resource for the work that Charlotte and Emily produced for M. Héger when they were studying in Brussels. Many of the essays are fascinating for their reflections upon political and historical concerns.

Langland, E. (1989). Anne Brontë: The Other One. Basingstoke: Macmillan. An important reassessment of Anne's work, which examines both the poetry and prose in its social, political, and literary contexts and which consequently recovers Anne from her traditional position as third—and lesser—sister. 
Matthew, C. (2000). The Nineteenth Century. Oxford: Oxford University Press.

An insightful and wide-ranging history of the nineteenth century which offers a range of important contexts for understanding the Brontës' political thinking and engagement. Orel, H. (1996). The Brontës: Interviews and Recollections. Basingstoke: Palgrave Macmillan.

A useful resource which brings together a series of views on the Brontës by their contemporaries and thereby situates them in their immediate social and political contexts. Rogers, P. (2003). “Tory Brontë: Shirley and the MAN.” Nineteenth Century Literature 58: $141-175$.

An important article for considering some of the directions in which Charlotte's politics developed in her mature fiction.

\begin{abstract}
This chapter examines the ways in which the Brontë family engaged with the wider concerns of politics, law, and reform in their lives and writings. In particular, it is concerned to trace the development of the siblings' political thinking in the period prior to the production of the sisters' mature fictions. It considers Patrick Brontë's important influence on the formation of his children's political thought and traces their growing political awareness through the development of the structures and narratives of Gondal and Angria. In revealing the political concerns at the heart of the sibling's poetry_concerns which are often explicit in Branwell's poetry and more oblique in that of the sisters - the chapter concludes by emphasizing the importance of this early work for the political engagements in the subsequent famous novels.
\end{abstract}

Keywords politics, law, reform, juvenilia, poetry, Patrick Brontë, Branwell Brontë, Charlotte Brontë, Emily Brontë, Anne Brontë 